\title{
Association of genetic variations in the $A C L Y$ gene with growth traits in Chinese beef cattle
}

\author{
M.N. Li, X. Guo, P.J. Bao, X.Y. Wu, X.Z. Ding, M. Chu, C.N. Liang and \\ P. Yan
}

Key Laboratory for Yak Breeding Engineering of Gansu Province, Lanzhou Institute of Husbandry and Pharmaceutical Sciences, Chinese Academy of Agricultural Sciences, Lanzhou, China

Corresponding author: P. Yan

E-mail: pingyanlz@163.com

Genet. Mol. Res. 15 (2): gmr.15028250

Received December 10, 2015

Accepted January 29, 2016

Published July 15, 2016

DOI http://dx.doi.org/10.4238/gmr.15028250

\begin{abstract}
ATP citrate lyase (ACLY) is the primary enzyme responsible for the synthesis of cytosolic acetyl-CoA, which is a key precursor of both fatty acid and mevalonate synthesis pathways. Genetic variation of the $A C L Y$ gene may influence multiple traits associated with animal production. Here, we identified three non-synonymous mutations in $A C L Y$ exons in five beef cattle populations using DNA pool sequencing and high-resolution melting analysis. Results from association analyses revealed that the single nucleotide polymorphism (SNP) g.17127C $>\mathrm{T}$ is significantly associated with chest girth $(\mathrm{P}<0.01)$ and body height $(\mathrm{P}<$ $0.05)$ in the Fleckvieh $x$ Zhangye local crossbred cattle, and with body slanting length $(\mathrm{P}<0.05)$ in the Simmental $x$ Guyuan local crossbred cattle. SNP g.40427T $>C$ is significantly associated with an increase in chest girth $(\mathrm{P}<0.05)$ in the Simmental x Huzhu cattle population. These results provide preliminary evidence that polymorphisms in the bovine $A C L Y$ gene are associated with growth traits in beef cattle in northwest China. However, a larger sample set is needed to validate these findings.
\end{abstract}

Key words: $A C L Y$ gene; Beef cattle; High-resolution melting; Growth traits 


\section{INTRODUCTION}

ATP citrate lyase (ACLY), encoded by the $A C L Y$ gene, is also called ATP citrate synthase, and was first identified in pigeon liver (Srere and Lipmann, 1953). ATP citrate lyase is a member of the acyl-CoA synthetase (ADP-forming) superfamily (Sánchez et al., 2000), and consists of ACLA and ACLB subunits (Fatland et al., 2002). In mammals, ACLY is a homotetramer, containing an ATP-grasp domain ( $\mathrm{N}$-terminal region), a CoA binding domain, a CoA-ligase, and citrate synthetase (C-terminal region) (Morita et al., 2014). Sun et al. (2010, 2011) successfully identified the citrate and ATP binding site of chymotrypsin-truncated human ACLY using X-ray crystallography, revealing the partial residue conformation of the 1101-amino acid protein.

ACLY is an enzyme that catalyzes the conversion of citrate to oxaloacetate and acetyl-CoA coupled with the hydrolysis of ATP to ADP in many oleaginous species (Watson et al., 1969). Acetyl-CoA is produced in the mitochondria and is required for fatty acid and cholesterol biosynthesis pathways (Chypre et al., 2012). Acetyl-CoA is transformed to citrate via the activity of citrate synthase and then exported to the cytoplasm, where ACLY regenerates acetyl-CoA (Sun et al., 2011). ACLY is believed to play an important role in lipid metabolism (Khwairakpam et al., 2015).

High-starch diets markedly increase the expression of ACLY in the longissimus lumborum of cattle at 56 days of feeding (Graugnard et al., 2010), and gradual increases in glucose and insulin upregulate ACLY expression in subcutaneous adipose tissue of midlactation dairy cows (Carra et al., 2013). Genome-wide linkage analysis demonstrated that $A C L Y$ located on BTA19 was involved in the biosynthesis of milk fat (Bouwman et al., 2011). Several investigations have focused on $A C L Y$ polymorphisms and their association with growth and carcass quality traits in pig (Muñoz et al., 2013; Davoli et al., 2014). In addition, the expression of $A C L Y$ is associated with intramuscular fat percentage in sheep (Guo et al., 2014). However, studies investigating the association of polymorphisms with growth traits in beef cattle in northwest China are limited.

The aim of our study was to investigate genetic variation in the $A C L Y$ gene in five beef cattle hybrid populations of northwest China using high-resolution melting (HRM) analysis, and to investigate the association between mutations and growth traits. The results of this study provide some useful information on cattle genetic resources. Moreover, the results helped to select the candidate marker for breeding excellent beef cattle breeds of northwest China.

\section{MATERIAL AND METHODS}

\section{DNA isolation and data collection}

A total of 170 beef cattle of various hybrid populations from northwest China were investigated at random. These crossbred cattle included Angus x Guyuan local hybrid cattle (AG, $N=41,12 \pm 2$ months old, Guyuan district of Ningxia Province), Simmental x Guyuan local crossbred cattle (SG, N = 38, $18 \pm 2$ months old, Guyuan district of Ningxia Province), Simmental x Huzhu local crossbred cattle $(\mathrm{SH}, \mathrm{N}=30,18 \pm 2$ months old, Huzhu district of Qinhai Province), South Devon x Pingliang local crossbred cattle (SDP, N = 31, $6 \pm 2$ months old, Pingliang district of Gansu Province), and Fleckvieh x Zhangye local crossbred cattle (FZ, N = 30, $12 \pm 3$ months old, Zhangye district of Gansu Province). Blood samples were collected from the jugular vein and treated with acid-citrate-dextrose anti-coagulation. 
Genomic DNA was isolated using a genomic DNA isolation kit (Tiangene, Beijing, China) according to the manufacturer instructions, and all DNA samples with OD 260/280 ratios $>1.8$ were diluted to $20 \mathrm{ng} / \mu \mathrm{L}$. All DNA samples were stored at $-20^{\circ} \mathrm{C}$ for subsequent analysis. The body dimensions of each animal were measured, including body height $(\mathrm{BH})$, body slanting length (SL), chest girth (CG), and cannon circumference (CC). In order to minimize errors, one person was assigned to measure each trait.

\section{PCR primers and amplification}

In this study, DNA pool sequencing was performed to identify single nucleotide polymorphisms (SNPs) in the bovine $A C L Y$ gene. The basic DNA pool unit consisted of DNA samples from 70 individuals that were selected at random. Based on the sequence of bovine $A C L Y$ (GenBank accession No. NC_007317.5), 19 pairs of primers were designed using the Primer Premier 5.0 software to amplify the $28 A C L Y$ exons including exon-intron boundaries (Table 1). Primers were synthesized by BGI (Beijing, China). The DNA pool described above was used as a template to amplify these regions.

Table 1. PCR primers used for sequencing and small amplicons in the high-resolution melting (HRM) analysis.

\begin{tabular}{|c|c|c|c|c|}
\hline Primer name & Primer sequence $\left(5^{\prime} \rightarrow 3^{\prime}\right)$ & Annealing temperature $\left({ }^{\circ} \mathrm{C}\right)$ & Amplicon type & Amplicon size (region) \\
\hline P1 & $\begin{array}{l}\text { F: GCGGTCAGGATAGGGAATG } \\
\text { R: GGAAGGCAGGCAACAACG }\end{array}$ & 58.4 & Sequencing & 474 (exon 1) \\
\hline P2 & $\begin{array}{l}\text { F: CGCACCCTTTGACCAGC } \\
\text { R: GGATTCTATCAGCCATCTACAC }\end{array}$ & 58.4 & Sequencing & 611 (exon 2) \\
\hline P3 & $\begin{array}{l}\text { F: GATACCACATAGGGAGGG } \\
\text { R: GCAATCGGACCAGTCAT }\end{array}$ & 56.8 & Sequencing & 670 (exon 3) \\
\hline P4 & $\begin{array}{l}\text { F: CCCATTGCCCTAGTTTCT } \\
\text { R: GTGCTGGTTCCTTTCTGC }\end{array}$ & 56.8 & Sequencing & 449 (exon 4$)$ \\
\hline P5 & $\begin{array}{l}\text { F: TTTGCGGCAGAAAGGAA } \\
\text { R: CAACTGTGGCGGGTCAA }\end{array}$ & 58.4 & Sequencing & $1346($ exon 5,6$)$ \\
\hline P7 & $\begin{array}{l}\text { F: AGAGTTGTGGATGGGTGAA } \\
\text { R: CCAGGGAGGTTGATTGAGA }\end{array}$ & 58.4 & Sequencing & 653 (exon 7) \\
\hline P8 & $\begin{array}{l}\text { F: GGCGGTGACTGGCTGTA } \\
\text { R: CGAGGGTTCCTGTTCTGT }\end{array}$ & 56.8 & Sequencing & 439 (exon 8) \\
\hline P9 & $\begin{array}{l}\text { F: GGGGCTTGAGTGTCTGA } \\
\text { R: TTCCCTTCCCTGCTTCC }\end{array}$ & 58.4 & Sequencing & $1071($ exon 9,10$)$ \\
\hline P11 & $\begin{array}{l}\text { F: TGTTCTCACCTCAGCACCAT } \\
\text { R: CCATCTTACCGACTTATCCC }\end{array}$ & 52.5 & Sequencing & 475 (exon 11$)$ \\
\hline P12 & $\begin{array}{l}\text { F: GGTGTCCATAGAGCCATTT } \\
\text { R: TCTCCGTGTCCCATTCC }\end{array}$ & 58.4 & Sequencing & $1064($ exon 12,13$)$ \\
\hline P14 & $\begin{array}{l}\text { F: CATCCTCTTGCCTTCCT } \\
\text { R: TCCCACCACTTTCACCTAA }\end{array}$ & 58.8 & Sequencing & $830($ exon 14,15$)$ \\
\hline P16 & $\begin{array}{l}\text { F: AGAGGCTGGTGGGAAGA } \\
\text { R: GCAGGAGCAGTCAGAACA }\end{array}$ & 56.8 & Sequencing & 381 (exon 16) \\
\hline P17 & $\begin{array}{l}\text { F: GGGACCTTTCGTCTTGG } \\
\text { R: ATGCCTGAGTTCCTTCG }\end{array}$ & 52.5 & Sequencing & 833 (exon 17) \\
\hline P18 & $\begin{array}{l}\text { F: GTTAGGTCCATACCATTTCT } \\
\text { R: GACGCCATCTCAACTCAT }\end{array}$ & 56.0 & Sequencing & 1306 (exon 18,19$)$ \\
\hline P20 & $\begin{array}{l}\text { F: AATCCGTTCTCCTTTGC } \\
\text { R: CATCTGCTACCCATTGTTC }\end{array}$ & 51.4 & Sequencing & 1143 (exon 20, 21) \\
\hline P22 & $\begin{array}{l}\text { F: CTGCCTGAGTCCACATTC } \\
\text { R: GCCTTCTTTGCTAACCCT }\end{array}$ & 56.0 & Sequencing & 742 (exon 22) \\
\hline P23 & $\begin{array}{l}\text { F: GTGTTAGACCTGGATTGGG } \\
\text { R: AAGAGTCACCTGGGAAGC }\end{array}$ & 56.0 & Sequencing & 880 (exon23, 24) \\
\hline P25 & $\begin{array}{l}\text { F: TGCTTGACGCTGTAGGA } \\
\text { R: TTAGGACCCAGATTTGAC }\end{array}$ & 49.2 & Sequencing & 1380 (exon $25,26,27)$ \\
\hline P28 & $\begin{array}{l}\text { F: CTTCCGCTTTGTCCTTG } \\
\text { R: GGCTTTAGTTGCTCCTC }\end{array}$ & 51.4 & Sequencing & 1420 (exon 28$)$ \\
\hline PH1 & $\begin{array}{l}\text { F: TCCTCACAGGGAAGACCAC } \\
\text { R: AGAGCAATGCCCACGATG }\end{array}$ & 57.0 & HRM & 82 \\
\hline PH2 & $\begin{array}{l}\text { F: CGTTCTCCTTTACATTTCAGGTCCA } \\
\text { R: AACACTCCAGCCTCCTTCAA }\end{array}$ & 57.8 & HRM & 109 \\
\hline PH3 & $\begin{array}{l}\text { F: CAGCCAAGATGTTCAGCAAG } \\
\text { R: GGTGACCAATGCCCATGATAA }\end{array}$ & 58.9 & HRM & 102 \\
\hline
\end{tabular}

P1-28 refer to the pairs of primers for scanning SNPs, PH1-3 refer to the pairs of primers for HRM analysis. 
Amplifications were performed in $12.5-\mu \mathrm{L}$ reactions containing $1 \mu \mathrm{L} 20 \mathrm{ng}$ genomic DNA, $0.4 \mu \mathrm{M}$ each primer, and 6.25 $\mu \mathrm{L}$ Taq PCR MasterMix (Tiangene). PCR was performed using the following program: 3 min at $94^{\circ} \mathrm{C}$, followed by 25 cycles of $30 \mathrm{~s}$ at $94^{\circ} \mathrm{C}, 30 \mathrm{~s}$ at the corresponding temperature (Table 1), and $40 \mathrm{~s}$ at $72^{\circ} \mathrm{C}$, with a final extension of $5 \mathrm{~min}$ at $72^{\circ} \mathrm{C}$. Amplifications were performed in a thermal cycler (Bio-Rad, USA).

PCR amplicons were purified with a Gel Extraction Mini Kit (Tiangene) and sequenced in both directions by BGI. The sequences were edited by the Chromas software, and then imported into MEGA 5 to identify SNPs.

\section{HRM analysis of small amplicons}

Based on the polymorphic sites detected, three pairs of primers were designed using the LightScanner Primer Design Software (Idaho Technology, USA) (Table 1). High and low calibrators were synthesized by Sangon (Bejing, China) according to the method described by Gundry et al. (2008).

HRM-PCR was performed in $10-\mu \mathrm{L}$ reactions containing $1 \mu \mathrm{L} 20$ ng genomic DNA, $0.2 \mu \mathrm{M}$ each primer, $5 \mu \mathrm{L}$ Taq PCR MasterMix (Tiangene), and $1 \mu \mathrm{L}$ 10X DNA dye LC Green (Idaho Technology). PCR was performed in a thermal cycler (Bio-Rad) using the following program: 5 min at $95^{\circ} \mathrm{C}$, followed by 35 cycles of $20 \mathrm{~s}$ at $94^{\circ} \mathrm{C}, 20 \mathrm{~s}$ at the corresponding temperature (Table 1), and $20 \mathrm{~s}$ at $72^{\circ} \mathrm{C}$, with a final extension of $10 \mathrm{~min}$ at $72^{\circ} \mathrm{C}$. Next, 0.1 $\mu \mathrm{M}$ each calibrator and $1 \mathrm{mM} \mathrm{NaCl}_{2}$ was included in the amplification reactions. After this, a final denaturation and reannealing protocol was performed, which increased the temperature to $95^{\circ} \mathrm{C}$ for $30 \mathrm{~s}$ followed by a $25^{\circ} \mathrm{C}$ hold for $30 \mathrm{~s}$. HRM analysis using small PCR amplicons was performed on a 96-well plate LightScanner (Idaho Technology). Data were analyzed with the LightScanner software (Idaho Technology).

\section{Statistical analysis}

Genotype and allelic frequencies were determined by counting and compared using the chi-square test among groups. Hardy-Weinberg equilibrium and haplotypes for each pair of segregating sites were determined using SHEsis. The Minitab software (version 16) was used to analyze the relationship between different genotypes of $A C L Y$ and the four growth trait parameters $(\mathrm{BH}, \mathrm{SL}, \mathrm{CG}, \mathrm{CC})$ recorded in various hybridized combinations. The following statistical model was used:

$$
Y_{i j}=\mu+G_{i}+S_{j}+\mathrm{e}_{i j}
$$

where $Y_{i j}$ is the phenotypic value of the target trait, $\mu$ is the population mean, $G_{i}$ is the $i$ th genotypes, $S_{j}$ is the effect of $j$ th sex, and $\mathrm{e}_{i j}$ is the random error.

\section{RESULTS}

\section{Analysis of sequence variation in the bovine $A C L Y$ gene}

All of the coding exons of $A C L Y$ were successfully amplified using pooled DNA as a template, and three polymorphic sites were detected by DNA pool sequencing. SNP 
g. $17127 \mathrm{C}>\mathrm{T}$ was located in exon 12, SNP g.35520C $>\mathrm{T}$ was located in exon 20, and SNP g.40427T $>$ C was located in exon 24. Amino acid sequence analysis at all SNPs revealed that the substitutions were synonymous and did not cause an amino acid change. Corresponding to human ACLY isoform 1 (GenBank accession No. NP_001087), SNP g.17127C $>$ T and g. 35520C $>\mathrm{T}$ were located at domain 5 and 2 , respectively.

Based on the melting temperature, different melting curves representing different SNP genotypes were exhibited upon HRM analysis. The melting curves for T/C variants are shown in Figure 1. Genotype distribution, allelic frequencies, and Hardy-Weinberg equilibrium values are shown in Table 2. Among the five populations investigated, allele C was found to be common at the loci g.17127C $>$ T, g.35520C $>\mathrm{T}$, and g.40427T $>$ C, and allele $\mathrm{T}$ for all mutations was rarer. CC and CT genotypes were detected in three variants of all five populations, and the TT genotype was not found. All three loci were in Hardy-Weinberg equilibrium $(\mathrm{P}>0.05)$. Genotypic distributions of SNP g.17127C $>$ T and SNP g.35520C $>$ T were significantly different among the five cattle populations $(\mathrm{P}<0.05)$. For the g.17127C $>\mathrm{T}$ locus, the $\mathrm{CC}$ genotype frequency in the $\mathrm{FZ}$ group was significantly higher than that in the $\mathrm{AG}$ and SG groups $(\mathrm{P}<0.01)$, which was significantly lower than the frequency in the SH group $(\mathrm{P}<0.05)$. A significantly higher frequency of the $\mathrm{CC}$ genotype of $\mathrm{g} .35520 \mathrm{C}>\mathrm{T}$ was observed in the AG group than in the SDP group $(\mathrm{P}<0.05)$. However, no significant differences were found at the g.40427T $>$ C locus.

A

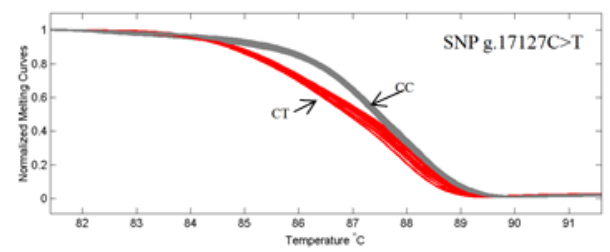

B

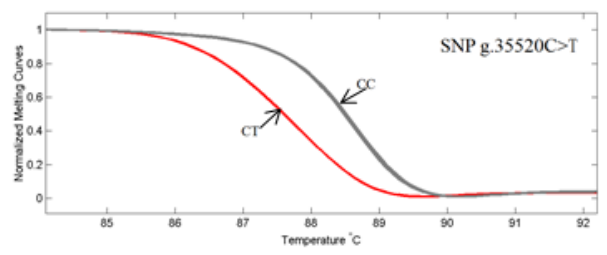

C

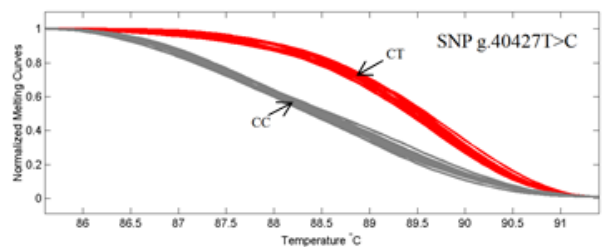

Figure 1. High-resolution melting curves (normalized) of the single nucleotide polymorphisms (SNPs) detected in this study. A. SNP g.17127C>T; B. SNP g.35520C > T; and C. SNP g.40427T >C. The curves are labeled by the SNP genotypes. The CT genotypes are presented as a red curve; the CC genotypes are presented as a gray curve. 
Table 2. Genotype distribution and allelic frequencies at polymorphic sites of the $A C L Y$ gene in five populations.

\begin{tabular}{|c|c|c|c|c|c|c|c|c|}
\hline \multirow{2}{*}{$\begin{array}{l}\text { Loci } \\
\text { g. } 17127 \mathrm{C}>\mathrm{T}\end{array}$} & \multirow[t]{2}{*}{ Population } & \multicolumn{2}{|c|}{ Genotype frequencies (\%) } & \multirow[t]{2}{*}{ P value } & \multirow[t]{2}{*}{$\chi^{2}$ (HWE) } & \multicolumn{2}{|c|}{ Allele frequencies (\%) } & \multirow[t]{2}{*}{$P$ value } \\
\hline & & $\mathrm{CC}$ & CT & & & $\mathrm{C}$ & $\mathrm{T}$ & \\
\hline & $\mathrm{AG}$ & $70.7^{\mathrm{a}}$ & 29.3 & \multirow[t]{5}{*}{$\mathrm{P}<0.01$} & $\mathrm{P}>0.05$ & 85.4 & 14.6 & \multirow[t]{5}{*}{$\mathrm{P}>0.05$} \\
\hline & SG & $71.1^{\mathrm{a}}$ & 28.9 & & $\mathrm{P}>0.05$ & 85.5 & 14.5 & \\
\hline & SH & $83.3^{\mathrm{b}}$ & 16.7 & & $\mathrm{P}>0.05$ & 91.7 & 8.3 & \\
\hline & SDP & $77.4 \mathrm{a}^{\mathrm{b}}$ & 22.6 & & $\mathrm{P}>0.05$ & 88.7 & 11.3 & \\
\hline & $\mathrm{FZ}$ & $86.7^{\mathrm{B}}$ & 13.3 & & $\mathrm{P}>0.05$ & 93.3 & 6.7 & \\
\hline \multirow[t]{6}{*}{ g. $35520 \mathrm{C}>\mathrm{T}$} & & $\mathrm{CC}$ & $\mathrm{CT}$ & & & $\mathrm{C}$ & $\mathrm{T}$ & \\
\hline & $\mathrm{AG}$ & $92.7^{\mathrm{b}}$ & 7.3 & \multirow[t]{5}{*}{$\mathrm{P}<0.05$} & $\mathrm{P}>0.05$ & 96.3 & 3.7 & \multirow[t]{5}{*}{$\mathrm{P}>0.05$} \\
\hline & SG & $89.5^{\mathrm{ab}}$ & 10.5 & & $\mathrm{P}>0.05$ & 94.7 & 5.3 & \\
\hline & SH & $86.7^{\mathrm{ab}}$ & 13.3 & & $\mathrm{P}>0.05$ & 93.3 & 6.7 & \\
\hline & SDP & $80.6^{\mathrm{a}}$ & 19.4 & & $\mathrm{P}>0.05$ & 90.3 & 9.7 & \\
\hline & $\mathrm{FZ}$ & $90.0^{\mathrm{ab}}$ & 10.0 & & $\mathrm{P}>0.05$ & 95.0 & 5.0 & \\
\hline \multirow[t]{6}{*}{ g. $40427 \mathrm{~T}>\mathrm{C}$} & & $\mathrm{CC}$ & CT & & & $\mathrm{C}$ & $\mathrm{T}$ & \\
\hline & $\mathrm{AG}$ & 68.3 & 31.7 & \multirow[t]{5}{*}{$\mathrm{P}>0.05$} & $\mathrm{P}>0.05$ & 84.1 & 15.9 & \multirow[t]{5}{*}{$\mathrm{P}>0.05$} \\
\hline & SG & 76.3 & 23.7 & & $P>0.05$ & 88.2 & 11.8 & \\
\hline & SH & 70.0 & 30.0 & & $\mathrm{P}>0.05$ & 85.0 & 15.0 & \\
\hline & SDP & 67.7 & 32.3 & & $\mathrm{P}>0.05$ & 83.9 & 16.1 & \\
\hline & $\mathrm{FZ}$ & 76.7 & 23.3 & & $\mathrm{P}>0.05$ & 88.3 & 11.7 & \\
\hline
\end{tabular}

Lowercase letters "a" and "b" denote significant different values at $\mathrm{P}<0.01$; uppercase "B" denotes significantly different values at $P<0.05$. $A G=$ Angus $x$ Guyuan local hybrid cattle, $S G=$ Simmental $x$ Guyuan local crossbred cattle, $\mathrm{SH}=$ Simmental $\times$ Huzhu local crossbred cattle, SDP $=$ South Devon $\times$ Pingliang local crossbred cattle, $\mathrm{FZ}=$ Fleckvieh $\mathrm{x}$ Zhangye local crossbred cattle.

\section{Haplotype and linkage disequilibrium analysis of $A C L Y$ in five cattle populations}

Six haplotypes were identified for the $A C L Y$ gene in five cattle populations (Table 3). Haplotype CCC was the dominant haplotype among the five populations, occurring at a frequency of 0.662-0.796. Haplotype CTC occurred at a significantly higher frequency in the SDP cattle than in the AG cattle. The frequency of the haplotype TCC was significantly higher in the AG and SG cattle than in the SH cattle. Linkage disequilibrium between the SNPs in all cattle populations was estimated (Table 4), and the results indicated that SNPs g.17127C $>$ T and g.40427T $>\mathrm{C}$ were in moderate linkage disequilibrium in the SH population $\left(r^{2}=0.280\right)$, and little linkage disequilibrium was found among the three sites in other populations.

Table 3. Haplotype distribution of three SNPs in the five populations.

\begin{tabular}{|c|c|c|c|c|c|c|}
\hline \multirow[t]{2}{*}{ Breed } & \multicolumn{6}{|c|}{ Haplotype } \\
\hline & $\mathrm{CCC}$ & CCT & CTC & CTT & TCC & TCT \\
\hline $\mathrm{AG}$ & 0.713 & 0.104 & $0.014^{\mathrm{a}}$ & 0.022 & $0.114^{\mathrm{b}}$ & 0.032 \\
\hline SG & 0.707 & 0.095 & $0.053^{\mathrm{ab}}$ & 0.000 & $0.122^{\mathrm{b}}$ & 0.023 \\
\hline SH & 0.776 & 0.074 & $0.055^{\mathrm{ab}}$ & 0.011 & $0.018^{\mathrm{a}}$ & 0.065 \\
\hline SDP & 0.662 & 0.128 & $0.097^{\mathrm{b}}$ & 0.000 & $0.080^{\mathrm{ab}}$ & 0.033 \\
\hline FZ & 0.796 & 0.087 & $0.050^{\mathrm{ab}}$ & 0.000 & $0.037^{\mathrm{ab}}$ & 0.029 \\
\hline
\end{tabular}

Lowercase letters "a" and "b" denote significantly different values at $\mathrm{P}<0.05 . \mathrm{AG}=$ Angus $\mathrm{x}$ Guyuan local hybrid cattle, $\mathrm{SG}=$ Simmental $\times$ Guyuan local crossbred cattle, $\mathrm{SH}=$ Simmental $\times$ Huzhu local crossbred cattle, $\mathrm{SDP}=$ South Devon $\mathrm{x}$ Pingliang local crossbred cattle, FZ = Fleckvieh $\mathrm{x}$ Zhangye local crossbred cattle.

\section{Association analysis of single markers and combined genotypes}

Association analyses between $A C L Y$ polymorphisms and growth traits (BH, SL, CG, and $\mathrm{CC}$ ) are shown in Table 5. For the g.17127C $>$ T locus, individuals with the genotype $\mathrm{CT}$ had greater $\mathrm{CG}(\mathrm{P}<0.01)$ than those with genotype $\mathrm{CC}$ in the $\mathrm{FZ}$ population, and the animals with genotype $\mathrm{CT}$ had significantly greater $\mathrm{BH}(\mathrm{P}<0.05)$ than those with genotype CC. Individuals with genotype CT had greater SL $(\mathrm{P}<0.05)$ than those with genotype CC in the SG population, demonstrating that the g.17127C $>\mathrm{T}$ polymorphism is significantly 
associated with growth traits in SG and FZ beef cattle. Furthermore, the SNP g.40427T $>$ C was significantly associated with an increase in CG $(\mathrm{P}<0.05)$ in the SH cattle population. However, no significant association was detected between the SNP markers and measured traits in the AG and SDP populations. These results reveal different behaviors among the five analyzed cattle populations, and the heterozygous individuals had higher body dimensions than individuals with homozygous genotypes.

Table 4. Linkage disequilibrium among three loci within the $A C L Y$ gene in five cattle populations.

\begin{tabular}{|c|c|c|c|c|c|}
\hline \multirow[t]{2}{*}{ Population } & \multirow[t]{2}{*}{ Loci } & \multicolumn{2}{|c|}{$D^{\prime}$} & \multicolumn{2}{|c|}{$r^{2}$} \\
\hline & & g. $35520 \mathrm{C}>\mathrm{T}$ & g.40427T $>C$ & g. $35520 \mathrm{C}>\mathrm{T}$ & g. $40427 \mathrm{~T}>\mathrm{C}$ \\
\hline \multirow[t]{2}{*}{$\mathrm{AG}$} & g. $17127 \mathrm{C}>\mathrm{T}$ & 1.000 & 0.031 & 0.007 & 0.001 \\
\hline & g. $35520 \mathrm{C}>\mathrm{T}$ & - & 0.525 & - & 0.056 \\
\hline \multirow[t]{2}{*}{$\overline{S G}$} & g. $17127 \mathrm{C}>\mathrm{T}$ & 1.000 & 0.074 & 0.009 & 0.004 \\
\hline & g. $35520 \mathrm{C}>\mathrm{T}$ & - & 1.000 & - & 0.007 \\
\hline \multirow[t]{2}{*}{ SH } & g. $17127 \mathrm{C}>\mathrm{T}$ & 1.000 & 0.738 & 0.006 & 0.280 \\
\hline & g. $35520 \mathrm{C}>\mathrm{T}$ & - & 0.442 & - & 0.002 \\
\hline \multirow[t]{2}{*}{ SDP } & g. $17127 \mathrm{C}>\mathrm{T}$ & 1.000 & 0.184 & 0.014 & 0.022 \\
\hline & g. $35520 \mathrm{C}>\mathrm{T}$ & - & 1.000 & - & 0.021 \\
\hline \multirow[t]{2}{*}{$\overline{F Z}$} & g. $17127 \mathrm{C}>\mathrm{T}$ & 1.000 & 0.369 & 0.004 & 0.074 \\
\hline & g. $35520 \mathrm{C}>\mathrm{T}$ & - & 1.000 & - & 0.007 \\
\hline
\end{tabular}

$\mathrm{AG}=$ Angus $\mathrm{x}$ Guyuan local hybrid cattle, $\mathrm{SG}=$ Simmental $\mathrm{x}$ Guyuan local crossbred cattle, $\mathrm{SH}=$ Simmental $\mathrm{x}$ Huzhu local crossbred cattle, $\mathrm{SDP}=$ South Devon $\times$ Pingliang local crossbred cattle, $\mathrm{FZ}=$ Fleckvieh $\mathrm{x}$ Zhangye local crossbred cattle.

Table 5. Associations between single SNPs and phenotypic traits in five populations of cattle.

\begin{tabular}{|c|c|c|c|c|c|c|}
\hline Loci & Population & Genotypes & $\mathrm{BH}(\mathrm{cm})$ & $\mathrm{SL}(\mathrm{cm})$ & $\mathrm{CG}(\mathrm{cm})$ & $\mathrm{CC}(\mathrm{cm})$ \\
\hline \multirow[t]{10}{*}{ g. $17127 \mathrm{C}>\mathrm{T}$} & \multirow[t]{2}{*}{ AG } & CC (29) & $117.1 \pm 2.194$ & $132.1 \pm 4.463$ & $162.0 \pm 5.168$ & $16.1 \pm 0.565$ \\
\hline & & CT (12) & $114.5 \pm 2.921$ & $143.5 \pm 5.898$ & $165.7 \pm 7.312$ & $15.6 \pm 0.936$ \\
\hline & \multirow[t]{2}{*}{ SG } & CC (27) & $120.9 \pm 2.584$ & $140.4 \pm 3.548^{b}$ & $174.2 \pm 5.148$ & $19.7 \pm 0.657$ \\
\hline & & CT (11) & $125.2 \pm 3.499$ & $148.6 \pm 4.804^{\mathrm{a}}$ & $183.0 \pm 7.011$ & $20.9 \pm 0.887$ \\
\hline & \multirow[t]{2}{*}{$\mathrm{SH}$} & CC (25) & $121.0 \pm 2.493$ & $143.1 \pm 4.845$ & $175.1 \pm 5.413$ & $16.6 \pm 0.486$ \\
\hline & & CT (5) & $121.2 \pm 4.045$ & $140.5 \pm 7.862$ & $166.2 \pm 8.745$ & $17.7 \pm 0.856$ \\
\hline & \multirow[t]{2}{*}{ SDP } & CC (24) & $103.8 \pm 3.087$ & $114.6 \pm 4.908$ & $128.2 \pm 5.470$ & $15.2 \pm 0.465$ \\
\hline & & CT (7) & $104.6 \pm 5.292$ & $115.8 \pm 8.414$ & $128.1 \pm 9.376$ & $14.5 \pm 0.797$ \\
\hline & \multirow[t]{2}{*}{ FZ } & CC (26) & $107.0 \pm 3.419^{b}$ & $129.4 \pm 5.029$ & $146.5 \pm 4.262^{\mathrm{B}}$ & $17.6 \pm 0.735$ \\
\hline & & CT (4) & $113.8 \pm 2.057^{\mathrm{a}}$ & $135.3 \pm 3.027$ & $160.8 \pm 2.565^{\mathrm{A}}$ & $18.9 \pm 0.442$ \\
\hline \multirow[t]{10}{*}{ g. $35520 \mathrm{C}>\mathrm{T}$} & \multirow[t]{2}{*}{ AG } & CC (38) & - & - & - & - \\
\hline & & CT (3) & - & - & - & - \\
\hline & \multirow[t]{2}{*}{ SG } & CC (34) & $123.7 \pm 1.916$ & $143.4 \pm 2.630$ & $178.4 \pm 3.815$ & $19.6 \pm 0.457$ \\
\hline & & CT (4) & $122.4 \pm 4.446$ & $145.6 \pm 6.103$ & $178.8 \pm 8.896$ & $21.0 \pm 1.162$ \\
\hline & \multirow[t]{2}{*}{ SH } & CC (26) & $120.5 \pm 1.846$ & $142.3 \pm 3.589$ & $172.6 \pm 3.962$ & $16.9 \pm 0.442$ \\
\hline & & CT (4) & $121.6 \pm 4.305$ & $141.2 \pm 8.367$ & $168.6 \pm 9.222$ & $17.4 \pm 0.813$ \\
\hline & \multirow[t]{2}{*}{ SDP } & CC (25) & $108.3 \pm 2.585$ & $119.6 \pm 4.110$ & $132.1 \pm 4.580$ & $15.4 \pm 0.389$ \\
\hline & & CT (6) & $100.1 \pm 5.866$ & $110.9 \pm 9.326$ & $124.2 \pm 10.393$ & $14.4 \pm 0.884$ \\
\hline & \multirow[t]{2}{*}{ FZ } & CC (27) & - & - & - & - \\
\hline & & CT (3) & - & - & - & - \\
\hline \multirow[t]{10}{*}{ g. $40427 \mathrm{~T}>\mathrm{C}$} & \multirow[t]{2}{*}{$\mathrm{AG}$} & CC (28) & $115.7 \pm 2.121$ & $141.3 \pm 4.049$ & $160.5 \pm 5.064$ & $15.7 \pm 0.676$ \\
\hline & & CT (13) & $115.8 \pm 2.938$ & $134.3 \pm 6.180$ & $167.1 \pm 7.145$ & $15.9 \pm 0.720$ \\
\hline & \multirow[t]{2}{*}{ SG } & CC (29) & $122.7 \pm 2.714$ & $143.0 \pm 3.726$ & $175.9 \pm 5.407$ & $19.9 \pm 0.695$ \\
\hline & & CT (9) & $123.4 \pm 3.466$ & $146.1 \pm 4.759$ & $181.4 \pm 6.939$ & $20.7 \pm 0.868$ \\
\hline & \multirow[t]{2}{*}{$\mathrm{SH}$} & CC (21) & $120.4 \pm 3.074$ & $138.2 \pm 5.975$ & $160.9 \pm 6.758^{b}$ & $17.3 \pm 0.568$ \\
\hline & & CT (9) & $121.8 \pm 3.094$ & $145.4 \pm 6.013$ & $180.4 \pm 6.712^{\mathrm{a}}$ & $17.1 \pm 0.716$ \\
\hline & \multirow[t]{2}{*}{ SDP } & CC (21) & $102.7 \pm 3.350$ & $109.7 \pm 5.326$ & $122.1 \pm 5.935$ & $14.4 \pm 0.505$ \\
\hline & & CT (10) & $105.6 \pm 4.935$ & $120.7 \pm 7.847$ & $134.2 \pm 8.744$ & $15.3 \pm 0.743$ \\
\hline & \multirow[t]{2}{*}{ FZ } & $\mathrm{CC}(23)$ & $110.2 \pm 2.321$ & $132.6 \pm 3.414$ & $152.8 \pm 2.893$ & $18.4 \pm 0.499$ \\
\hline & & CT (7) & $110.5 \pm 2.966$ & $132.2 \pm 4.364$ & $154.5 \pm 3.698$ & $18.1 \pm 0.638$ \\
\hline
\end{tabular}

Results reported as means \pm standard error. The genotypes $(\mathrm{N}<3)$ were neglected in this analysis. Lowercase letters "a" and " $\mathrm{b}$ " denote significantly different values at $\mathrm{P}<0.05$; uppercase letters " $\mathrm{A}$ " and "B" denote values significantly different at $\mathrm{P}<0.01 . \mathrm{AG}=$ Angus $\mathrm{x}$ Guyuan local hybrid cattle, $\mathrm{SG}=$ Simmental $\mathrm{x}$ Guyuan local crossbred cattle, $\mathrm{SH}=\mathrm{Simmental}$ $\mathrm{x}$ Huzhu local crossbred cattle, SDP = South Devon $\mathrm{x}$ Pingliang local crossbred cattle, FZ = Fleckvieh $\mathrm{x}$ Zhangye local crossbred cattle, $\mathrm{BH}=$ body height, $\mathrm{SL}=$ body slanting length, $\mathrm{CG}=$ chest girth, $\mathrm{CC}=$ cannon circumference. 


\section{DISCUSSION}

ACLY acts as a cross-link between pathways involved in carbohydrate metabolism and the production of fatty acids (Chypre et al., 2012). As a key precursor for fatty acid and mevalonate synthesis pathways (Zaidi et al., 2012), acetyl-CoA, which is produced in mitochondria, is transformed to citrate by citrate synthase, then citrate is exported to the cytoplasm where ACLY catalyzes the conversion of citrate into oxaloacetate and acetyl-CoA (Sun et al., 2011). The ACLY gene, which encodes ATP citrate lyase and is associated with the tricarboxylic acid cycle, might help to sustain the lipogenic process (Graugnard et al., 2010). In addition, the expression of $A C L Y$ has been strongly correlated with intramuscular fat in sheep and cattle (Guo et al., 2014). Davoli et al. (2014) investigated two SNPs in the porcine $A C L Y$ gene and found significant associations between polymorphisms and the productive traits average daily gain, ham weight, and back fat thickness. Therefore, ACLY might be an important biomarker for growth traits in animals.

Bovine ACLY was mapped to chromosome 19, and contains 28 exons and 27 introns. To better understand the distribution of genetic variation in bovine $A C L Y$, diversity was explored in five beef cattle hybrid populations from northwest China including Angus, Simmental, South Devon, and Fleckvieh. As a result, limited polymorphisms were revealed within the $A C L Y$ coding region, with all three variants identified being synonymous. Those results showed that bovine $A C L Y$ has low polymorphism, and that the coding region is relative conservative (Li et al., 2012). Synonymous variants do not result in an amino acid change in the protein, although they may affect the level of protein expression, protein conformation, or function (Sauna and Kimchi-Sarfaty, 2011). More SNP markers may be identified as more samples are collected from more breeds.

ACLY is a member of the acyl-CoA synthetase superfamily (ADP-forming), which consists of separate $\alpha$ and $\beta$ subunits, or a fusion of $\alpha-\beta$ protein (Sánchez et al., 2000). All five domains of human ACLY are common constitutes of this superfamily. Corresponding to human ACLY isoform 1 (GenBank accession No. NP_001087), residues 2-425 form domains 3,4 , and 5 , and all three of these domains are homologous to the $\beta$ subunit of succinyl-CoA synthetase. Residues 487-820 form domains 1 and 2, which are homologous to the $\alpha$ subunit of succinyl-CoA synthetase (Sun et al., 2010). In the present study, two SNPs g.17127C $>$ T and g.35520C $>$ T identified in bovine $A C L Y$ were found to be located in domains 5 and 2 of human ACLY isoform 1, respectively. Domain 5 forms the citrate binding site, and domain 2 possesses a phosphohistidine loop, which binds in the $C$ termini of $\beta$ strands corresponding to the structure of the human ACLY protein (MMDB ID: 94227). Of note, the SNPs in bovine $A C L Y$ may be relevant to the binding site of ATP and citrate in bovine, and may have functional relevance for the role of the bovine ACLY protein.

Two SNPs in porcine $A C L Y$ were found to be associated with important productive traits in Italian Large White and Duroc pigs (Davoli et al., 2014). We further evaluated whether three mutations in $A C L Y$ could account for differences in the measured traits of the five hybrid populations. In this study, gene-specific SNP marker analysis showed that SNP g. $17127 \mathrm{C}>\mathrm{T}$ is significantly associated with $\mathrm{CG}(\mathrm{P}<0.01)$ and $\mathrm{BH}(\mathrm{P}<0.05)$ in the $\mathrm{FZ}$ population, and is also significantly associated with SL $(\mathrm{P}<0.05)$ in the SG population, and the SNP g.40427T $>$ C is significantly associated with an increase in CG $(\mathrm{P}<0.05)$ in the SH cattle population. However, no significant association was detected between the markers and measured traits in AG and SDP populations. It is possible that SDP beef cattle ( $6 \pm 2$ months old) were younger 
than the other cattle, and that the expression of ACLY differs during animal development (Chypre et al., 2012). Another explanation for this might be the different breeding history among the five populations. All of the five populations presented in this study were different cross-combinations. No significant association was detected between SNP g.35520C $>$ T and measured traits in five populations; however, the number of samples used in this study was limited. To our knowledge, this is the first report describing SNPs in the whole exon region of the bovine $A C L Y$ gene and their effects on growth traits. These results provide preliminary evidence that bovine $A C L Y$ gene polymorphisms are associated with growth traits in beef cattle of northwest China; however, a larger set of samples is needed to validate the results.

\section{Conflicts of interest}

The authors declare no conflict of interest.

\section{ACKNOWLEDGMENTS}

Research supported by the Innovation Project of Chinese Academy of Agricultural Sciences (\#CAAS-ASTIP-2014-LIHPS-01) and the Program of National Beef Cattle and Yak Industrial Technology System (\#CARS-38).

\section{REFERENCES}

Bouwman AC, Bovenhuis H, Visker MH and van Arendonk JA (2011). Genome-wide association of milk fatty acids in Dutch dairy cattle. BMC Genet. 12: 43-55. http://dx.doi.org/10.1186/1471-2156-12-43

Carra M, Al-Trad B, Penner GB, Wittek T, et al. (2013). Intravenous infusions of glucose stimulate key lipogenic enzymes in adipose tissue of dairy cows in a dose-dependent manner. J. Dairy Sci. 96: 4299-4309. http://dx.doi.org/10.3168/ jds.2012-6242

Chypre M, Zaidi N and Smans K (2012). ATP-citrate lyase: a mini-review. Biochem. Biophys. Res. Commun. 422: 1-4. http://dx.doi.org/10.1016/j.bbrc.2012.04.144

Davoli R, Braglia S, Zappaterra M, Redeghieri C, et al. (2014). Association and expression analysis of porcine ACLY gene related to growth and carcass quality traits in Italian Large White and Italian Duroc breeds. Livest. Sci. 165: 1-7. http://dx.doi.org/10.1016/j.livsci.2014.04.010

Fatland BL, Ke J, Anderson MD, Mentzen WI, et al. (2002). Molecular characterization of a heteromeric ATP-citrate lyase that generates cytosolic acetyl-coenzyme A in Arabidopsis. Plant Physiol. 130: 740-756. http://dx.doi.org/10.1104/ pp. 008110

Graugnard DE, Berger LL, Faulkner DB and Loor JJ (2010). High-starch diets induce precocious adipogenic gene network up-regulation in longissimus lumborum of early-weaned Angus cattle. Br. J. Nutr. 103: 953-963. http://dx.doi. org/10.1017/S0007114509992789

Gundry CN, Dobrowolski SF, Martin YR, Robbins TC, et al. (2008). Base-pair neutral homozygotes can be discriminated by calibrated high-resolution melting of small amplicons. Nucleic Acids Res. 36: 3401-3408. http://dx.doi. org/10.1093/nar/gkn204

Guo B, Kongsuwan K, Greenwood PL, Zhou G, et al. (2014). A gene expression estimator of intramuscular fat percentage for use in both cattle and sheep. J. Anim. Sci. Biotechnol. 5: 35-47. http://dx.doi.org/10.1186/2049-1891-5-35

Khwairakpam AD, Shyamananda MS, Sailo BL, Rathnakaram SR, et al. (2015). ATP citrate lyase (ACLY): a promising target for cancer prevention and treatment. Curr. Drug Targets 16: 156-163. http://dx.doi.org/10.2174/1389450115 $\underline{666141224125117}$

Li AM, Lan XY, Sun XM, Gao Y, et al. (2012). Genetic variations of ANGPTL6 gene and their associations with growth traits and slaughter traits in Qinchuan cattle. Mol. Biol. Rep. 39: 9223-9232. http://dx.doi.org/10.1007/s11033-012-1795-5

Morita T, Koike H, Hagiwara H, Ito E, et al. (2014). Genome and transcriptome analysis of the basidiomycetous yeast Pseudozymaantarctica extracellular glycolipids, mannos ylerythritol lipids. PLoS One 24: 86490. http://dx.doi. org/10.1371/journal.pone. 0086490 
Muñoz M, Fernández AI, Benítez R, Pena RN, et al. (2013). Disentangling two QTL on porcine chromosome 12 for backfat fatty acid composition. Anim. Biotechnol. 24: 168-186. http://dx.doi.org/10.1080/10495398.2012.763130

Sánchez LB, Galperin MY and Müller M (2000). Acetyl-CoA synthetase from the amitochondriate eukaryote Giardia lamblia belongs to the newly recognized superfamily of acyl-CoA synthetases (Nucleoside diphosphate-forming). $J$. Biol. Chem. 275: 5794-5803. http://dx.doi.org/10.1074/jbc.275.8.5794

Sauna ZE and Kimchi-Sarfaty C (2011). Understanding the contribution of synonymous mutations to human disease. Nat. Rev. Genet. 12: 683-691. http://dx.doi.org/10.1038/nrg3051

Srere PA and Lipmann F (1953). An enzymatic reaction between citrate, adenosine triphosphate and coenzyme A. J. Am. Chem. Soc. 75: 4874. http://dx.doi.org/10.1021/ja01115a547

Sun T, Hayakawa K, Bateman KS and Fraser ME (2010). Identification of the citrate-binding site of human ATP-citrate lyase using X-ray crystallography. J. Biol. Chem. 285: 27418-27428. http://dx.doi.org/10.1074/jbc.M109.078667

Sun T, Hayakawa K and Fraser ME (2011). ADP-Mg2+ bound to the ATP-grasp domain of ATP-citrate lyase. Acta Crystallogr. Sect. F Struct. Biol. Cryst. Commun. 67: 1168-1172. http://dx.doi.org/10.1107/S1744309111028363

Watson JA, Fang M and Lowenstein JM (1969). Tricarballylate and hydroxycitrate: substrate and inhibitor of ATP: citrate oxaloacetate lyase. Arch. Biochem. Biophys. 135: 209-217. http://dx.doi.org/10.1016/0003-9861(69)90532-3

Zaidi N, Swinnen JV and Smans K (2012). ATP-citrate lyase: a key player in cancer metabolism. Cancer Res. 72: 3709 3714. http://dx.doi.org/10.1158/0008-5472.CAN-11-4112 